\title{
TRANSDISCIPLINARY APPROACH IN MODERN PSYCHOLOGY
}

\section{Abstract}

The paper looks at key transformations of the contemporary situation requiring new methodological strategies in psychology, and evolution of science in the $20^{\text {th }}$ century from interdisciplinary to trans-disciplinary. The latter takes the form of a strategy for analyzing complex and dynamic phenomena with the help of combined methods and contextual application of research optics borrowed from related disciplines. Methodologically transdisciplinarily serves as the basis for the integration of cognitive practices and research techniques, development of the holistic outlook, with the expansion of intellectual capacity as its educational side-effect. Conceptually trans-disciplinarily is expressed in several interpretations. Piaget, one of the founders of the approach, viewed it as a higher and more complex stage of integration of knowledge than interdisciplinarity. Contemporary interpretations of trans-disciplinarily vary from emphasizing the fluidity of cognitive space to general principles of cognitive activity seeking mathematical expression. The transdisciplinary start of contemporary science is characterized by the fact that each discipline is viewed as both a sovereign and open system; development of cognition takes place in the antinomies of tradition and innovation: changes and breakthroughs happen by means of borrowing experience from related disciplines while preserving own scientific identity. Key characteristics of trans-disciplinarily are cognitive movement through disciplines; transparence of disciplinary boundaries: the dissolution of dominant paradigms. Human life space in a transitive society, which is variable, multi-dimensional and complex, can only be understood on the basis of comparison and integration of knowledge within the framework of the transdisciplinary approach.

Keywords: methodology, modernity, transdisciplinary approach, transitive society, identity.

\section{Introduction}

The psychology of XXI century has a habit of self-reflection and comprehension of selfdevelopment in horizons of transforming social-cultural contexts. For modern Russian psychological science, this means that transformation happening in the global world find 
immediate and fundamental comprehended embodiment in psychological concepts. In the latter case, they become the subject of close attention and methodological study; in the first, they proceed in a hidden, unchanging, latent form. The concept of modernity has entered the research field of psychology (Grebennikova et al., 2017 Grishina, Kostromina, 2017; Sergienko, 2012, et al.) has been expressed in methodological discussions (Gusel'tseva, 2015, 2017; Gusel'tseva, Izotova, 2016; Martsinkovskaya, 2012, 2015). The changed sociocultural context contributed to the search for new methods, approaches, and epistemological strategies focused on such qualities of the world as transitivity, diversity, super-complexity, multidimensionality, ambiguity (Asmolov, 2015; Barnett, 2011; Martsinkovskaya, 2015).

In Russian psychological science, in response to these methodological challenges, integrating and communicative strategies (Kozlov, 2003; Mazilov, 2008) and problemoriented, and network approaches were developed (Zelenkova, 2007), the principal orientation on knowledge synthesis on interdisciplinary arose (Znakov, 2015, 2016, 2017; Leontiev, 2011, 2016; Podd'yakov, 2014, Sergienko, 2011, et al.). The works of foreign authors are also devoted to the problem of mixed methods and integrative strategies (see, e.g., Arcidiacono, De Gregorio, 2008; De Lisele, 2011, Dell Porta, Keating, 2008, Denzin, Sridhar, 2010, Kimchi, Polikova, Stevenson, 1991; Morse, 1991; Terrell, 2012, and others) Starting in 2007, the American publishing house "Sage Publication" has quarterly published Journal of Mixed Methods Research, which discussed both the possibilities and risks of a theoretical mix (Johnson et al., 2007).

The increased communication of psychology with related sciences today contributes to its progress towards transdisciplinary cognition. A new view, taking into account the factors of transitivity, complexity, multidimensionality, ambiguity and diversity, is a methodological prerequisite for understanding the mutual conditioning and productive interference of those cognitive areas that were previously considered the subject of individual sciences consideration. Transformations of the surrounding world, a change in the psychological qualities of a person in this world, an update of the toolbar and representations of modern psychological science, that studies these changes and new properties of identity - all this together forms a single field of analysis in the focus of the transdisciplinary approach.

\section{General provision of transdisciplinarity}

Transdisciplinary research and its general ideas nowadays are represented in some interpretations. Recall that, for the first time, this term arose in the discussions of J. Piaget with astrophysicist E. Yanch and mathematician A. Likhnerovich (Grebenshchikova, 
Kiyashchenko, 2011). At the same time, J. Piaget asserted that transdisciplinarity is a higher and more complex stage in the integration of knowledge than interdisciplinarity (Piaget, 1971, 1972). Modern concepts of transdisciplinary are distinguished by implicit implications of methodological monism, liberalism or pluralism: some focus on the integration of knowledge, on its single-centrism (Mokij, 2009), while others focus on holism and mobility (Kiyashchenko, Moiseev, 2009; Knyazeva, 2011), and the third group - on the sensitivity to nuances (Moren, 2012). The latest model shows that the completeness and integrity of knowledge is not necessarily built on its centric organization.

Interpretations of transdisciplinary extend from emphasizing the fluidity of cognitive space to the general and mathematical expressed principles of cognitive activity. Transdisciplinary research strategies suggest that democratic knowledge and its polyphony; building more complex pictures of the world; the encyclopedic level of the scientist; multilevel study of a specific problem (for example, in a combination of its global and local biological and cultural aspects); the new principle of knowledge organization (openness of disciplined boundaries, the interaction of disciplines). It should be mentioned that the forms of this research organization were also comprehended by other names: multidisciplinary, pluridisciplinarity, interdisciplinary (Mokij, 2009). The stages of development of the transdisciplinarity problem are reflected in a number of concepts that have received the following legends: transdisciplinary -1 , transdisciplinary -2 , transdisciplinary -3 , transdisciplinary - 4. The first stage, as already was mentioned, was presented by a discussion of J. Piaget, E. Yanch, and A. Likhnerovich at a seminar on the problems of university education (Apostel et al., 1972), where the idea of constructing a more complex research model rather than interdisciplinarity was discussed. The result of the second development stage of this problem was the Charter of transdisciplinary, adopted at the I World Congress on Transdisciplinarity in Portugal in 1994. The principle is holism was considered here as the leading one in knowledge organizing process (http://anoitt.ru/inde.php). Transdisciplinary -3 represented by the approach of L.P. Kiyashchenko and V.I. Moiseeva (2009). Transdisciplinarity - 4 is based on the principle of single-centrism in research conduction (Mokij, 2009).

From the position of V.S. Mokij, transdisciplinarity is "a way to expand the scientific worldview, which consists in examining a particular phenomenon, not limited to the framework of any scientific discipline" (Mokij, 2009, p. 13). For E.N. Knyazeva, it is primarily a "research strategy that crosses disciplinary boundaries and develops a holistic vision" (Knyazeva, 2011, p. 194). In the narrow sense, transdisciplinarity "means the integration of various forms and methods of research, including special examples of scientific knowledge, 
to solve scientific problems," whereas, in the broader sense, it is "the unity of knowledge beyond the boundaries of specific disciplines" (Knyazeva, 2011, p. 194). In our opinion, we are talking about the possibility of presenting a transdisciplinarity approach at different levels of the methodology of science - specifically scientific and generally accessible. In this regard, transdisciplinarity is understood by us as a strategy for the analysis of complex and dynamic phenomena, which implies a conscious, variably, situational, conditional use of methodological optics of various disciplines. The transdisciplinary state of modern science is characterized by the fact that each discipline is simultaneously considered as a sovereign and open system; in the antinomies of tradition and innovation; changes in it are made by borrowing the experience of related disciplines while maintaining their own scientific identity.

\section{Methodology of transdisciplinarity}

History demonstrates not only progressive but also rhythmic development, where the trends of integration and differentiation both coexist in the same social space and alternate in the historical genetic perspective of analysis. Thus, in the evolution of scientific knowledge, from time to time, the desire for universalism, for a planetary strategic thinker and encyclopedic knowledge comes to the fore. The milestones of this phenomenon are, first of all, the birth of anthology, and then the formation of the science of the Renaissance. At the beginning of the $20^{\text {th }}$ century, interdisciplinarity began to play an important role in the progressive development of scientific knowledge, encouraging representatives of different disciplines to enter into communication and thereby expanding intellectual horizons, optimizing their own scientific achievements.

A methodological understanding of this process led to the emergence of ideas and concepts about the heuristic nature of the borderline areas of knowledge and the creative transfer (epistemological "transition") of methods and conceptual structures from one science to another (Avtonomova, 2008; Bakhtin, 1979; Rabinovich, 1979).

The interdisciplinary approach has developed and evolved (changed) throughout XX century, however, in the prospect of modern cognitive situation, we can discuss previously unobvious differences between inter-, multi- and transdisciplinarity (Gusel'tseva, 2016; Knyazeva, 2011). So, interdisciplinarity is an implicit cognitive model of fundamentally open science, where a particular science, discipline or branch of knowledge goes beyond its disciplinary boundaries, starting to use the results, achievements, and strategies of other sciences to solve their own cognitive tasks in their own disciplinary territory. The multidisciplinarity can be described as a cognitive model for problem-oriented research where for solving designated problem experts' opinion are used and knowledge of 
specialists from different sciences; as a rule, such a research activity is organized in a "round table" format (or in modern format - online conference). Multidisciplinary approach as a special scientific trend became evident and meaningful approximately at the end of the XX century. Its main difference from the interdisciplinary approach is that while solving exact problem researcher tries to find or construct such a perspective on the comprehension of diverse material, which allows to review and generate necessary integral knowledge about the problem. Thus, here we can stress out the growing constructivism and the role of subjectivity in the production of scientific knowledge.

If in the context of the disciplinary matrix for the development of classical science, an average scientist just had to follow the rules and procedures, then multidisciplinarity requires the efforts of personal creativity, the intellectual search for the observer's position, where the chaos of empirical data is a meaningful picture or a theoretical gestalt. Ideally, the scientist himself is forced to invent the principle of combining dissimilar material (as a rule, this is a situational principle, i.e., acting in relation to the conditions and circumstances of the local situation). Transdisciplinarity is characterized by movement through discipline; it is the fundamental openness of disciplinary boundaries and the dissolution of paradigm limits in the sense that there is no predetermined matrix of research thinking, and the methods, path, methodology are built along the course of the study itself. A similar research strategy is presented in the methodology of science as the epistemology of complexity by E. Moren (2012). Note that the prefix "trans-", emphasizes the flow of research, inevitably refers to both the characteristics of modernity in the optics of social knowledge ("fluid modernity") and the general style of the post-non-classical type of thinking. The processes of continuous transformation of our modernity are reflected in such fixative terms as transitivity, transparency, transcultural, transnationality, transdisciplinary, transgression, transgender, transhumanism, etc. It is the unstable, labile, fluid, contradictory, incomplete state of the world and identity in this world that required psychological science to search for new methodological strategies (Gusel'tseva, 2015, 2016).

Similarly, to the historical change in the types of rationality, inter-, multi- and transdisciplinary form, a kind of epistemological "nesting doll"(матрешка), where interdisciplinary connections enhance creativity at the junctions and in the frontier of sciences; multidisciplinary attitudes create new holistic knowledge in the friction of different ways of vision and in search of consensus; finally, all this is loaded in the context of a changing, constantly modernizing world, where there are transdisciplinary strategies changing the effect of entropy, build reliable (secure) concepts from unstable material. It is the paradoxical stability of network (contextually variable, situational and unsteady) 
methodological strategies that make them the most effective in a transdisciplinary model of cognition.

\section{Transdisciplinary research movements in Psychology}

Like the famous hero of Moliere did not realize that he talked by prose, in modern Russian psychology the tendency to transdisciplinarity is implemented in a number of approaches (within the framework of this article we will touch upon only a few of them). We also note that some time ago, a similar situation was observed in the development of postnon-classical rationality in psychological science. Among the new approaches that make it possible to comprehend psychological changes in modern transitive society from the standpoint of transdisciplinarity, we should note primarily subjective-analytical (Znakov, 2015), system-subjective (Sergienko, 2011, 2016), compliant (Podd'yakov, 2014), existential (Leontiev, 2011, 2016) and other approaches. What new borders of studying the phenomenology and patterns of psychological development in modern transitive society allow us to consider and focus the above approaches?

V.V. Znakov, based on the ideas of S.L. Rubinstein on the world of the individual as a totality of different modes of his existence, shows the multidimensionality of this reality, which consists, at least, of the empirical, socio-cultural and existential layers of being (Znakov, 2016, 2017). As for human cognition, if in empirical reality, knowledge is built on relatively objective and quite material facts, then the understanding of sociocultural reality deals with different interpretations and changing opinions of people, as well as new meanings of events or situations generated by people. In turn, existential reality relies on experience, feeling, and also includes unconscious phenomena and unconscious motivation (Znakov, 2016, 2017). Thus, the human world and its psychological state in a transitive society demonstrate the phenomenology of diversity (identity, lifestyles, ways of perceiving), multidimensionality and complexity, which require understanding through the integration of knowledge within the framework of a transdisciplinary approach.

Nevertheless, it is important to note that V.V. Znakov insists on preserving interdisciplinary strategies in modern research, justifying it as follows: "An interdisciplinary analysis of the person's problems should be precisely interdisciplinary: in it, the psychological approach should be leading, formulating tasks and transforming the methods of other sciences to solve them. It is interdisciplinary, and not transdisciplinary, according to which sciences are equal, and only the problematic cognitive scheme that unites them is important "(Znakov, 2017, pp. 43-44). Along with this, V.V. Znakov honestly believes that the human world, which has become distorted in the 21 st century, entails the formation of a 
new outlook on classical psychological problems and the need for an application of an interdisciplinary, metacognitive and metasystem approaches in psychology. Moreover, the leading aspect of these changes in the methodological optics of psychological science becomes a presentation of ideas about "self-consciousness, self-damaging, selftransformation, the nature of human subjectivity" (Znakov, 2017, p. 51).

In our opinion, the orientation towards equal knowledge is not so much a transdisciplinary approach as such, but rather a separate postmodern interpretation: when solving specific psychological problems, the transdisciplinary approach is capable of being in methodological traditions of psychological science, while preserving the psychological analysis as the leading one. Its priority quality here remains not only conceptual tolerance, as much as contextual flexibility and resilience and transforming ability during the problemsolving process. The study of the features of human development in modern transitive society from the perspective of a complicological approach allows not only to catch the current psychological changes but also to describe their mechanism in situations of increased complexity, high dynamics, uncertainty, lability of ambivalence and antinomy of tasks, simultaneously demonstrating that occurring changes require from the supporting person the creative type of thinking. This approach is latent transdisciplinary in nature, comparing psychological knowledge with the achievements of the theory of complex dynamic systems, mathematical theories, logic and data of sociology (Podd'yakov, 2014).

E.A. Sergienko from the perspective of interparadigmal analysis reveals possibilities of a substantial rapprochement of domestic psychological schools of the 20th century, showing that if in the context of one era and a general (non-classical) paradigm, Soviet psychological approaches - for example, the activity approach of A.N. Leontiev and the substitution of S.L. Rubinstein's individual-activity approach, have distanced and opposed each other, then from the present through transdisciplinary methodological optics they represent as a conceptual unity of the intellectual tradition of cultural-operational psychology (Sergienko, 2016). Herewith, not only the change in the optical perspective (from the "microscope" as a tendency of differentiation and demarcation within one era to the "telescope" as the search for the prospect of modern integration), but also the installations of communicative openness today create opportunities for coordinated actions of historical-genetic, historical and evolutionary, cultural-analytical, systemic-subjective, subjective-analytical and other approaches.

In other words, transdisciplinary methodological optics allows us to present the conceptual diversity and historical confrontation of domestic psychological schools (the cultural and historical concept of L.S. Vygotsky, the theory of activity of A.N. Leontiev and 
the theory of activity of S.L. Rubenstein, the systematic approach of B.F. Lomov, subjectively-operational approach of A.V. Brushlinsky, the integrated approach of B.G. Ananyev, et al.) as a common intellectual heritage, which is not only assimilated by new generations of psychologists in the process of their professional education but also involves the selective design of approaches depending on the solution of current practical problems. This demonstrates the capabilities and limitations of various concepts, complemented by the perspectives of other concepts. According to E.A. Sergienko (2016), the historicalevolutionary approach of A.G. Asmolova, relying on synergetic and evolutionary epistemology, considering the issues of invariant and diversity in biological, social and mental systems development, not paying enough attention to the concept of "person", which indicates the source of uniqueness, self-development and the generation of new meanings. A cultural-analytical approach to the study of the evolution of psychological knowledge, focusing on cultural factors, but overlooking the micro-architectonics of the development of individuality and subjectivity, deserves similar criticism. However, these research gaps fully reveal and complement the systemic-subjective (Sergienko, 2011) and subjective-analytical approaches (Znakov, 2015, 2017). The permissive possibilities of the transdisciplinary approach are also manifested in the comparison of multilevel phenomena. Thus, a methodological review of the study of the person's problem in modern psychology reveals a lack of psychological vocabulary, where, on the one hand, the terms "person" or "individual" in different approaches encompass qualitatively different psychological realities, and on the other hand, there is no consensual general psychological concept that describes a person with positions of his psychological maturity, integrity, and integrity (Gusel'tseva, 2018). In this situation, the concept of "identity" sometimes comes to the rescue, which today claims to be inter- and transdisciplinary status. Studying the characteristics of psychological development in a transitive society leads to a change in the research view - open to new experience and taking into account conflicting socio-cultural trends. Transdisciplinary methodological optics here reveals new perspectives for studying the changed identity of a person in connection with the key transformations of modernity, where the finished and established concepts often impede the ability to see a fundamentally new reality. In addition, the development of a transdisciplinary approach contributes to the advancement of psychology towards the humanitarian sciences, whereby the turn of the XX-XXI centuries an arsenal of diverse methodological strategies for the comprehensive study of man and his activities in a changing culture has been accumulated and continues to develop intensively (see, for example, Modern methodological strategies, 2014). 


\section{Conclusion}

The fundamental importance of the transdisciplinary approach to the study of a person in a transitive society is based on the fact that such features of modern research reality as super complexity, uncertainty, fluidity, diversity, etc., encourage the development of a subtler, flexible and able to catch and integrate the multidimensionality of human being methodological toolkit. The evolution of the sociocultural and intellectual movements represented today is subject to the principle of displacement and mixing, forming complex dynamics (from linearity to multidimensionality, heterogeneity and layering; from stable trends to unpredictable shifts; from clear lines to subtle and tangled patterns). Establishing patterns within the framework of one or even several analytical perspectives, we could successfully extrapolate them in the absence of other trends. However, it is the presence of the latter, their interaction and hanging that surprise unexpected system properties, making the overall picture even more contradictory, unsteady and confusing. A constructive methodological way out of this state of affairs is combining perspectives in the conceptual framework of a transdisciplinary approach, which allows not only to detect but often to anticipate new qualities of the reality being studied. Thus, a wide range of cognitive practices, analytical constructs, methodologies and strategies open up for modern researchers. Interdisciplinarity acts as a phenomenon of mature modernism, often partially rely on methodological monism and include an implicit assumption of a pre-existing (or prevailing in a particular science) method. Multidisciplinarity is based on dialogism and methodological pluralism, and the necessary methods are most often constructed in the course of an ongoing study. Transdisciplinarity strengthens the aspects of knowledge fluidity and proceeds from the premise that the desired method is not only found but also continually modified under the influence of the configuration of contextually changing and developing processes and situations. Moreover, it is transdisciplinarity that creates and enhances the cognitive practice of a variety of epistemological paradigms (polyparadigmality), where the researcher spontaneously or arbitrarily and reflexively constructs his own methodological strategy.

\section{References}

Avtonomova N.S. Poznanie i perevod. M.: ROSSPEN, 2008.

Asmolov A.G. Psikhologiya sovremennosti: vyzovy neopredelennosti, slozhnosti i raznoobraziya // Psikhol. issled.: elektron. nauch. zhum. 2015. T, 8. N 40. S. 1. URL: http://psystudy.ru 
Barnett R. Osmyslenie universiteta //Obrazovanie v sovremennoj kul'ture. 2001. Al'manakh 1. URL: http://charko.narod.ru/tekst/alm1/barnet.htm

Bakhtin M.M. Estetika slovesnogo tvorchestva. M.: Iskusstvo, 1979.

Grebennikova O.V. i dr. Sotsial'nye predstavleniya I tsennostnye orientatsii v kartine mira sovremennykh podrostkov: mozaika protivorechij / Grebennikova O.V, Khuzeeva G. R., Konchalovskaya M. M., Ayanyan A.N. // Psikhol. issled.: elektron. nauch. zhum. 2017.T.10. N 53. S.5. URL: http://psystudy.ru

Grebenshchikova E.G., Kiyashchenko L.P. Tiansdistsiplinarnaya paradigma obrazovaniya $v$ <<obshchestve znaniya>> - pozitivnaya utopichnost' problematizatsii // Utopiya i obrazovanie: Sb. tr.Mezhdunarodnoj nauchnoprakticheskoj konferentsii (26-28 oktyabrya 2011 e. Moskva). Tomsk: Tomskij gos. pedagog. un-t, 2011. S. 52-60.

Grishina N.V., Kostromina S.N. Psikhologiya lichnosti: pereosmyslenie traditsionnykh podkhodov $v$ kontekste vyzovov sovremennosti // Psikhol. issted.: elektron. nauch. zhurn. 2017.T 10. N 52. S. 1. URL: http://psystudy.ru/

Gusel'tseva M.S. Identichnost'v tranzitivnom obshchestve: transformatsiya tsennostei // Psikhol. issled.: elektron. nauch. zhurn. 2017.T.10. N 54. S. 5. URL: http://psystudy.ru/

Gusel'tseva M.S. Kul'turno-analiticheskij podkhod k sotsializatsii lichnosti v tranzitivnom obshchestve // Psikhologiya osobistosti: Naukovij teoretikometodologichnij i prikladnij psikhologichnij zhurnal. 2013. N 1 (4). S. 20-38.

Gusel'tseva M.S. Printsip razvitiya v sovremennoj psikhologii: vyzovy poliparadigmal'nosti i transdistsiplinarnosti // Razrabotka i realizatsiya printsipa razvitiya $v$ sovremennoj psikhologii / Pod red. A.L. Zhvravleva, E.A. Sergienko. M.: IP RAN, 2016. S.31-51.

Gusel'tseva M.S. Psikhologiya i novye metodologii: epistemologiya slozhnogo // Psikhol. issled.: elektron. nauch. zhum. 2015. T 8. N 42. S. 11. URL: http://psystudy.ru

Gusel'tseva M.S. Rozhdenie psikhologii sub"ektivnosti iz dukha chelovekoznanya //Yoprosy psikhologii. 2018. N 1. S. 3-15.

Gusel'tseva M.S., Izotova E.I. Pozitivnaya sotsializatsiya detej i podrostkov: metodologiya i empirika. M.: Smysl, 2016.

Zetenkova T.Y. O setevoj paradigme v psikhologii / / Metodologiya i istoriya psikhologii . 2007. T. 2-Vyp. 3.S.18-28.

Znakov V.V. Mir cheloveka i sovremennaya psikhologiya sub"ekta // Integrativnyj podkhod k poznan iyu psikhologii cheloveka: V. N. Panferov, V.V. Znakou E.YU. Korzhova 
i dr' / Pod nauch. red. E.Yu. Korzhovoj. SPb.: Izd-vo RGPU im. A.L Gertsena,2017. S. 30-53.

Znakov Z. Z. Psikhologiya ponimaniya mira cheloveka. M.: IP RAN, 2016.

Znakov V.V. Sub"ektno-analiticheskij podkhod v psikhologii ponimaniya // Psikhol. issled.: elektron. nauch. zhurn. 2015. T 8. N 42' S. 12. URL: http://psystudy.ru

Informatsionnaya epokha: vyzovy cheloveku / otv. red.: I.YU. Alekseeva, A.YU. Sidorov. M.: ROSSPEN.2010.

Kiyashchenko L.P., Moiseev V.I. Filosohya transdistsiplinarnosti. M.: In-t filosofii RAN' 2009.

Knyazeva E.N. Tiansdistsiplinarnye strategii issledovanij // vestn. TGPU (TSPU Bulletin)' 2011. N 10 (112). s. 93-20r.

Kozlov V.V. Integrativnaya psikhologiya: v poiskakh tselostnosti // Tr. Yarosl. metodol. seminara. Yaroslavl': MAPN. 2003. T. 1. S. 187-204

Leontiev D.A. Novye orientiry ponimaniya lichnosti $v$ psikhologii: of neobkhodimogo $k$ vozmozhnomu [New reference points for understanding personality in psychology: From the necessary towards the possiblel / / Vopr. psikhol. 2011. N 1. s. 3-27.

Leontiev D.A. Ekzistentsial'nyj podkhod $v$ sovremennoj psikhologii lichnosti [The existentialist approach in contemporary psychology of personality // Voprosy psikhologii, 2016. N 3. S. 3-15.

Mazilov V.A. Integratsiya psikhologicheskogo znariya: metodologicheskie problemy. M. : MAPN, 2008.

Martsinkovskaya T.D. Informatsionnaya sotsializatsiya $v$ izmenyayushchemsya informatsionnom prostranstve // Psikhol. issled.: elektron. nauch. zhum. 2012.T.5. N 26. S. 7. URL: http://psystudv.ru

Martsinkovskaya L. D. Sovremennaya psikhologiya - vyzovy tranzitivnosti // Psikhol. issled.: elektron. nauch. zhurn' 2015. T. 8. N 42. S. 1. http://psystudy.ru

Mokij V. S. Osnovy transdistsiplinarnosti. Nal'chik: El'-Fa, 2009.

Moren E. Razmyshleniya o poznanii // Vestn. Evropy. 2012. N 33. http://magazines.russ.ru/vestnik/20 12/33/m30 -Pr.html

Podd'yakov A.N. Komplikologiya: sozdanie razvivayushchikh, diagnostiruyushchikh i destruktivnykh trudnostej. M.: Vysshaya shkola ekonomin, 2014.

Rsbinovich V.L. Alkhimiya kak fenomen srednevekovoj kul'tury.M.: Nauka. 1979.

Sergienko E.A. Mezhparadigmal'nye mosty // Psikhol. issled.: elektron. nauch. zhum. 2016. T 9. N 48. S.4. URL: http://psystudy.ru 
Sergienko E.A. Model' psikhicheskogo kak integrativnoe ponyatie $v$ sovremennoj psikholoeii // Psikhol. issled.: elektron. nauch. zhurn. 2017. T 10' N 54. S. 7. URL: http://psystudy.ru

Sergienko E.A. Printsipy psikhologii razvitiya: sovremennyj vzglyad // Psikhol. issled.: elektron' nauch. zhum. 2012.T.5. N 24. S. 1. URL: http://psystudy.ru

Sergienko E.A. Sistemno-sub"ektnyj podkhod: obosnovanie i perspektiva // Psikhol. zhurn. 2011. T 32. N 1. S. 120-132.

Sovremennye metodologicheskie strategii: Interpretatsiya. Konventsila. Perevod // Koll. monografiya /Pod obshch. red- B.I. Pruzhinina, T. G. Shchedrinoi. M.: Politicheskala entsiklopediya, 2014. 